\title{
Students Perceptions of Using Educational Games to Learn Introductory Programming
}

\author{
Roslina Ibrahim (Corresponding author) \\ Advanced Informatics School, Malaysia University of Technology (UTM) \\ Jalan Semarak, 54100, Kuala Lumpur, Malaysia \\ Tel: 60-3-2615-4616 E-mail: lina@ic.utm.my \\ Rasimah Che Mohd Yusoff \\ Advanced Informatics School, Malaysia University of Technology (UTM) \\ Jalan Semarak, 54100, Kuala Lumpur, Malaysia \\ Tel: 60-3-26154538Ｅ-mail: rasimah@ic.utm.my
}

Hasiah Mohamed@Omar

Faculty of Computer and Mathematical Sciences, Universiti Teknologi MARA (UiTM)

Dungun Campus, 2300 Dungun, Terengganu, Malaysia

Tel: 60-9840-3835 E-mail: hasia980@tganu.uitm.edu.my

\author{
Azizah Jaafar \\ Faculty of Technology and Information Science \\ Malaysia National University (UKM), Bangi, Selangor, Malaysia \\ Tel: 60-3-8921-5555 E-mail: aj@ftsm.ukm.my
}

\begin{abstract}
Educational computer games studies experienced rapid growth due to the belief that games can offer various learning benefits being highly popular among younger generations. Programming is considered a challenging subject by students and teachers, consequently students feel less motivated to learn it. It is important to know how educational games can help to enhance our student's motivation and learning perceptions towards Programming. This paper discusses the authors' pilot study of undergraduate students' perceptions towards using educational games as their learning medium using five constructs: motivation, attitudes, cognitive development, interface and expectation with 24 items. The findings indicated that most students had encouraging positive attitudes and were more motivated to learn Programming using games compared to conventional methods. The findings are hopefully will help to enrich knowledge in understanding students' perceptions regarding educational games for learning, particularly in the Malaysian context.
\end{abstract}

Keywords: Educational game, Programming, Perception

\section{Introduction}

Scholars believe educational games (EG) can offer many learning benefits for the students based on the highly motivating nature of the computer games itself as well as because of the behavior of the new generation of learners (Chang \& Chou, 2008), (Rajaravivarma, 2005). Some researchers suggested that games are able to offer as much as 16 learning benefits such as risk-taking, problems solving, interaction, situated meaning, exploration, team working (Gee, 2006). Gee also stated that games are able to teach high order thinking skills such as problem solving, team working, critical thinking and so on.

Evidence from studies of using educational games for learning has shown that students are highly interested with the games. Looking at the Malaysia scenario, (Rubijesmin, 2007) have found about $96 \%$ of male primary and secondary students play computer games while $90 \%$ female claimed to do so. She also indicated that most Malaysian students are familiar with many genres of computer games and playing games also encourages social skills among the students. The findings from Nor Azan and Wong (2008) indicated that $92 \%$ of secondary students 
(form 4) have experience in playing computer games. Students also used various games platforms and play games for various reasons. They have suggested that games can be used as an alternative approach to teach subject with low motivation among the students. Study by Roslina, Rasimah and Azizah (2008) found that 100\% of year 1 and year 2 students in a local university play computer games. In fact, about $35 \%$ of them play games almost every day. Most students also agree to use games as their learning approach (89\%). This indicated that games have penetrated the Malaysian market and younger generations' preferences need to be considered when designing learning materials.

Previous studies have found that using educational games as a learning approach can enhance student's learning of various learning domain: namely cognitive, affective as well as psychomotor skills (Garris, Ahlers, \& Driskell, 2002). A study by Zuhaira (2007) indicated that about $96 \%$ students feel that game help them to understand the subject content. Students also gain higher motivation to study (88\%) and they are more motivated to learn (100\%). Norizan (2003), found that EG does help to increase student motivation. A study by Garzotto (2007) revealed that multiplayer online games provided learning benefits on affective level as well as knowledge domain. Students were found enjoying the games, always engaged, motivated, and excited during the game play session. EG encompass a wide range of activities that can support playing, entertainment and learning, teaching on many disciplines. A number of studies also demonstrated the effectiveness of games in education (Lieberman D.A, 2001), (Virvao, 2005), (Hill, 2006), (Sugimoto, 2007). According to them, game motivates learning, offer immediate feedback, support skills, and influences changes in behavior and attitudes. Thus, the motivation provided by games should be taken as an opportunity to further explore its possibilities of use in education. Table 1 is the summary of literatures in using games to learn programming subject.

Programming is among the most important subject for computer science students. Student's achievement and competitiveness are measured by programming skills learned during their studies. However, teaching and learning programming subject is never an easy task as mentioned by many studies (Rajaravivarma, 2005), (Chang \& Chou, 2008), (Eagle \& Barnes, 2009), (Muratet, Torguet, Jessel, \& Viallet, 2009). This is due to complexity of the subjects that requires understanding of abstracts concepts, logical thinking as well as problem solving (Moser, 1997) as well as high level of abstraction (Olga, Pavel, Alexander, \& Alexey, 2009). Other studies also supported that learning programming subjects is difficult (Takemura, Nagumo, Huang, \& Matsumoto, 2007), (Nacke, 2004). Issues in learning programming are also not new; they are being discussed from a long time ago. According to (Baldwin \& Kuljis, 2000) academics have reported various methods used to teach programming subject, many issues were discussed but the problems are still there. (Simon, Lister, \& Fischer, 2006) said that many academics worry about their students facing difficulties in understanding the subject. Those researches showed that programming subject is difficult to learn and to teach.

A study by a group of researcher (Zarina, Alis@Alias, Hanawi, \& Arsad, 2005) on why programming students failed, revealed among others, incompetent students as well as incompetent lecturers. Among reasons stated by students are: i) did not understand lecturer's explanations, ii) did not finish course tutorial iii) copying from friends and iv) did not even try to answer questions from main text books. In a preliminary research done by the authors we reported that students found programming a boring subject, lecturers explanations are difficult to understand, teaching method that is not interesting, and not enough exercises or practices during class lesson (Roslina \& Nazli, 2009). Students also think that they need more exercises to learn the subject more effectively.

Based on above studies about lacks of motivation to study programming and high motivation of playing games, we proposed to integrate these two items together. Our objective is to understand user initial perceptions regarding use of games in their learning. Findings of the study will be used to further extend our research accordingly. We design our games with intention to induce motivation for students learning programming. We integrate exercises and lecture notes with games design characteristics using selected games genres. The games will complement our conventional lecture-class method. The games are hope to provide more motivation for student self learning of programming concepts, which later hopefully help to developed and enhance their interest to learn the subject.

The following sections will cover on research framework and methodology (in section 2), followed by section 3 for data analysis and findings, section 4 on discussions and future research and lastly section 5 for the conclusions.

\section{Research Framework and Methodology}

Research framework is described in the following section: Educational games design characteristics (explains about the combination of game characteristics needed for a good educational games design) and educational game model (explains about the integration of the characteristics into a game model for self learning and motivation). The model derived upon integration with Input-Process-Outcome Game Model proposed by Garris in (Garris et al., 2002). Research methodology discussed on the game development and econd part is the 
development of educational games, and data collection process.

\subsection{Educational Games Design Characteristics}

Issues of EG design comes from various perspectives such as psychology, education as well as technology (Grassioulet, 2002). Games involved human and technology, thus these two aspects need careful attentions. Adding the "educational' part into the games itself prompted another dimension - education, the tricky dimension that has been discussed from a long time ago. Education in itself has evolved and need to change according to human and technology development.

An educational game, one designed for learning, is a subset of both play and fun. (Prensky, 2001) define educational games as a melding of educational content, learning principles, and computer games. Another definition is by (Olga, Voroblakov, Kataev , \& Tarasenko, 2008) whom defined it as a learning system, which realizes some or all components of learning process (learning theory, gaining skills and experience and estimation of knowledge level) in a game context. Jaspaljeet (2008) defined educational games as games that have been specifically designed to teach people about certain subject, expand concepts, reinforce development, understand an historical event or culture, or assist them in learning a skill as they play. Generally, educational computer games is a game which combined both game design principles and learning theories with integration of learning content of specific subject or learning outcomes purposely to enrich learning for intended audiences.

Psychologists defined perception is defined as a single unified awareness derived from sensory processes while a stimulus is present. We present the educational games as the stimulus in order to understand our student's awareness of using games as a learning approach.

Games purposely designed for education definitely requires some degree of effectiveness in order to be accepted by stakeholders. Researchers suggested that effective games should combine good game design and good pedagogy (Oblinger, 2006), (Amory \& Seagram, 2003), (E. O. Klopfer, Scot. Salen, Katie, 2008). Games design here means similar concepts applied in entertainment games that should be adapted into educational games so it can offer certain degrees of engagement as in entertainment games. Our game design part consists of fun aspect including challenges, goals, feedback, and game story. These elements are derived from the concepts of game as describe by various authors (Novak, 2008), (Garzotto, 2007). These elements are said to be crucial in a games to really behave as a game as in (Owen, 2004), (Prensky, 2001), (Sauvé, 2007), (E. Klopfer \& Scot O, 2008), (Grassioulet, 2002). Without those elements, games cannot really be claim as a games, but rather similar with edutainment concepts which many have found not really relevant anymore as suggested by Klopfer ans Scot (2008).

Pedagogically, the games will be designed based on learning outcomes as stated in course syllabus at our university and match with the authentic syllabus as suggested by (Fisch, 2005), (Lepper \& D.I, 1992). The learning outcomes will be based on first three level of Bloom's taxonomy: knowledge, comprehension and application. Another concept is scaffolding, a concept applied to provide feedback in a form of learning material to enhance students' learning process (Fisch, 2005), (Graci, 1992). Finally, this game will be designed for self learning purposes: to be used by students to enhance their understanding and assess their learning performance. Details of the game design characteristics and pedagogical concepts are presented in the previous paper (Roslina \& Azizah, 2009). These concepts were integrated into game model proposed by Garris, Ahlers and Driskell (2002). Figure 1 is the conceptual framework of our game design.

\subsection{Model for Educational Games Design}

Garris et al (2002) proposed a model from integration of literatures related to instructional game called Input-Process-Outcome Game Model. They believed that the most important thing in using games is to motivate learners, intrinsically as well as extrinsically - to develop learners who are self-directed and self motivated. They believed that there is a tacit model of learning that is inherent in most studies of instructional games. First, the objective is to design an instructional program that incorporates certain features or characteristics of games. Second, these features trigger a cycle that includes user judgments or reactions such as enjoyment or interest, user behaviours such as greater persistence or time on task, and further system feedback. To the extent that we are successful in pairing instructional content with appropriate game features, this cycle results in recurring and self-motivated game play. Finally, this engagement in game play leads to the achievement of training objectives and specific learning outcomes. This is parallel with our purpose of designing our online games: promoting self motivation to learn Programming by using online games. Thus, we believed that this model is suitable to be adapted into our game design. The proposed educational games learning model for self learning is shown in Figure 2. The model is operationalised as explained below. 
Firstly, the model is to incorporate web based learning content with certain characteristics of online games as discussed in the previous section. Secondly, this model forms an online game environment surrounded by game activities with related information resources. Also, the games trigger a cycle that includes learner feedback on different sub game activities that through game rules and procedure for game based scaffolding. Finally, these activities in game play leads to achievement of learning outcomes. Games activities here are viewed as iterative that the game play involves repeated judgement-behaviour-feedback loops. That is, game plays lead to certain user judgements or reactions such as increased interest, enjoyment, and involvement or confidence. The concern is to make user continually return to the game activity over the time. This repeated activity and exercises is supposed to enhance students understanding of Programming concepts to desirable levels as stated in the learning outcomes. Table 2 shows the mapping of game design with the proposed model.

\subsection{Methodology}

For the initial usage of the model, two types of mini online EG have been designed and developed. The games were crossword and duck shooting types. We used the common games genre with the goal that for students do not spend time learning how to play the games They start right away to play (and learn). Learning contents were adapted from the chapters Introduction to Programming. Each game has three levels that can be accessed after finishing prior levels. The game design integrated proposed game characteristics to maintain its fun aspect. Findings from this study will be used to further enhance our game design and development. We planned to develop a compendium of mini games to convey learning content of this subject as suggested by (Frazer, Argles, \& Wills, 2007). They suggested that mini-games have lots to offer, some cases can cover almost all of the educational requirements proposed, provided the design concerned on information, formulaic game play and provide context for the content. Figure 3 and Figure 4 are the screen shots of the two games.

The pilot study is to understand student's perceptions of using educational games for learning. Samples are 21 first year diploma students taking the subject (15 females and 6 males) from Universiti Teknologi Malaysia (UTM) Kuala Lumpur. This was the actual number of students taking the subject at that time. We used a set of questionnaire with 5 constructs (motivation, attitudes, cognitive development, interface design and expectation) with 24 items and an open ended question on student's open comments about learning using the games. The questionnaire items were adapted and modified from Masrom (2006).

\section{Analysis and Findings}

This section discussed the findings according to constructs presented. We used the 1 to 5 point Likert Scale (strongly agree - agree - not sure - not agree - strongly disagree) respectively. In the analysis, we simplified it to 3 points for better readability. The data was analyzed using SPSS 13.0. The results were presented using percentage, mean and standard deviations. Reliability statistics of all 24 items used is using Cronbach's Alpha with the value of 0.970 .

Table 3 shows students' motivation in using the games for their learning. The noticable finding from this construct is students found using games makes the programming subject more interesting $(86 \%)$, and only $14 \%$ of them not sure about it. Students also prefer to do their exercises by using games rather than doing quizzes given by lecturers during class (81\%). More than half of the students, (67\%) prefer answering questions using games compared to using books or papers. Students think that the activities of using games for learning give them a lot of benefits towards their learning $(76 \%)$. More than $80 \%$ of the students are interested in using games for their future way of learning. This shows that students are highly motivated with the idea of using educational games for their learning with more than $80 \%$ of them agreeing that games makes the subject more interesting and their preferences of using games to do their exercises.

Table 4 shows the student's attitude in using games. Almost $60 \%$ of the students agree that they can learn by themselves better from using the games. They also agree that by using the games, they can learn according to their own self pace (67\%). This can help students to understand the subject content in the way that they prefer without feeling the pressure from their surroundings such as friends or lecturers. More than half of the students found it more flexible for them to determine their own learning time as they can download the games from the internet. Also, they have more flexibility in choosing their place to learn. Students also found that the content of the games match the syllabus of the subject, however, the percentage is only $62 \%$ probably due to the limited chapters (first three chapters only) of subject syllabus used in this research.

Table 5 is about students' cognitive development by using the games. Almost $80 \%$ of the students agree that the educational games help them to think critically. Furthermore, they found it very interesting to solve the problems given in the games $(81 \%)$. More than $75 \%$ of them found that looking for answer of given questions was an encouraging activity. About $71 \%$ of the students agree that the game does challenge their understanding of 
programming subject. Probably because of above the factors, more than $80 \%$ of the students said it is worth to try educational games for learning in the future. Findings of this factor show that student found playing educational games is a challenging activity as well as help them to think critically.

Table 6 shows the analysis on the game interface. Interface is important to determine the success of EG, games with good educational content but poor usability will have difficulties achieving intended educational results (MacFarlane \& Gavin Sim, 2005). About 67\% students found that the menus are easy to understand. They also said that the navigations and instructions are easy to use; also the multimedia elements in the game are interesting to them. Almost $60 \%$ also said that the uses of color and design layout in the games are interesting. The most obvious agreement from the students is regarding the time needed to know how the games functions $86 \%$ of them said that they need a very short time learn how to play the game.

Last construct is students' expectation in using the games for their learning (refer table 7). This section is to know how the students' view learning with games. Most students wish that they have more opportunities to use games as a learning approach $(71 \%)$. Surprisingly, $86 \%$ of the students prefer to use games in learning compared to traditional class. Similarly, $86 \%$ of them also like to learn other computer subjects using educational games. This is an indicator that our students' style and preferences have changed and we as educators have to understand preferences of our new generation of learners.

Students also wish that the games will be available online for their easy access (77\%) that would be the feature of our future research. Students open comments on the games are also very encouraging. Some of the comments are shown in Table 8. Students found that learning is much more fun by using games, in fact 20 of them gave positive comments on using games for learning, only one student suggested that educational game is fun but may not suitable as the only learning approach. Encouraging comments from students instigate our interest to further our research in using educational games in helping to enhance students learning.

\section{Discussions and Future Work}

This study suggested that students have anticipated high interest in using games as one of their learning activity. They have shown great motivation to use the games especially in doing their exercises, and games somehow makes the subject more interesting. This indicated that games might be suitable for certain subjects, for example subject that gain low motivation among student. The use of games may be one of the solutions that might arouse student interest to learn. Students also show positive attitudes in using games and they have acknowledged their cognitive development such as thinking critically and challenging their understanding about the subject. We consider game interface as important because navigating through the games should be free of effort, or else, students might find it difficult to use and lead to disappointment and abandonment of the games.

Based on students' expectations, we were highly encouraged to further and expand our research accordingly. They have shown great interest to use games in their learning. However, due to the infancy in educational games research especially in Malaysia, great attention needs to be taken in several issues in game design such as games genre, design for different learning outcomes, design for different learning styles and students. Besides, educational game development is no way an easy task due to its multidisciplinary needs such as game developers, content expert, and instructional designers, as well as user preferences.

Our future works will be strengthening the game design including interface, navigation and interactions, and integration of more programming contents. Then we will conduct the evaluation of students programming skills before and after using the games using more number of samples.

\section{Conclusions}

This paper describes the perceptions of students in a Malaysian university (UTM) towards using educational games for self-learning of Programming Introductory subject. Five constructs were used to measure the perceptions: namely motivation, attitude, cognitive development, games interface and expectation. The authors have gathered several features of games design and combined them with pedagogy features to leverage a good educational game design. The features are then integrated with Input Process Output Model by Garris et al (2002) to encourage motivation factor into educational games.

Findings indicated that most students were highly interested in using the games as one of their learning approach as this might be due to interactivity as well as embedded games design characteristics together with scaffolding concept that offer immediate feedback to the student. In addition, this is totally new experience for them as we have never introduced games to complement their usual way of learning in the past. Furthermore, Programming Subject is found as a difficult and boring subject; thus, learning with games seems to develop students' motivation on the subject. 
Limitations of this study are as follows. Since this study discusses student's perceptions by using two mini games: crossword and shooting games, our result are narrowly based on this games genre. The experience we gather during game design process suggested that these game genres are more suitable to represent knowledge level such remembering or memorization. It can also be used for comprehension level but careful questions designs are needed. Other limitation is small number of samples use in survey and it will also be more interesting to investigate the difference between male and female.

Games can be seen as a promising approach to enrich the learning methods in our university that mostly uses traditional lecture-based teaching method. Hopefully, this study will provide better understanding of students' related factors in using games for self-learning especially in Malaysian scenario.

\section{References}

Amory, A., \& Seagram, R. (2003). Educational game models: conceptualization and evaluation. South African Journal of Higher Education, 17(2), 206-217.

Chang, W.-C., \& Chou, Y.-M. (2008). Introductory C Programming Language Learning with Game-Based Digital Learning. Paper presented at the Proceedings ICWL 2008.

Eagle, M., \& Barnes, T. (2009). Experimental evaluation of an educational game for improved learning in introductory computing. ACM SIGCSE Bulletin, 2009, 321-325.

Fisch, S. M. (2005). Making Educational Games "Educational". Paper presented at the Conference on Interaction Design and Children IDC 2005.

Frazer, A., Argles, D., \& Wills, G. (2007). Is Less Actually More? The Usefullness of Educational Mini-Games. Paper presented at the IEEE International Conference on Advanced Learning Technologies (ICALT 2007).

Garris, R., Ahlers, R., \& Driskell, J. E. (2002). Games, Motivation, and Learning: A Research and Practice Model. Simulation and Gaming, 33(4), 441-467.

Garzotto, F. (2007). Investigating the Educational Effectiveness of Multiplayer Online Games for Children. Paper presented at the Interaction Design and Children (IDC 2007), Aalborg, Denmark.

Graci, C., Odendahl, R., \& Narayan, J. (1992). Children, chunking, and computing. Journal of Computing in Childhood Education 3(3/4), 247-258.

Grassioulet, Y. (2002). A Cognitive Ergonomics Approach to the Process of Game Design and Development. Unpublished Masters Thesis, University of Geneva.

Hill, J. (2006). Impacts of playing video games on learning in children. Literature Synthesis for Applying Research Retrieved October 2010, from jinayang.myweb.uga.edu/edit6900/resources/report.pdf

Jaspaljeet, S. L. L. W., Mohana Shanmugam,Saraswathy Shamini Gunasekaran, Siva Kumar Dorairaj. (2008). Designing Computer Games to Introduce Programming to Children. Paper presented at the Information Technology and Multimedia at UNITEN (ICIMU' 2008).

Klopfer, E., \& Scot O, J. G., Jason H. (2008). The Instructional Power of digital games, social networking and simulations and how teachers can leverage them. from http://www.academiccolab.org/resources/documents/MacArthur.pdf

Klopfer, E. O., Scot. Salen, Katie. (2008). Moving Learning Games Forward: Obstacles, Opportunities and Openness. The Education Arcade Retrieved October 2010, from education.mit.edu/.../MovingLearningGamesForward_EdArcade.pdf

Lepper, M. R., \& D.I, C. (1992). A desire to be tought: Instructional consequences of intrinsic motivation. Journal of Motivation and Emotion, 16(3), 187-208.

Lieberman D.A. (2001). Management of chronic pediatric diseases with interactive health games: theory and research findings Journal of Ambulatory Care Management, 24(1), 26-38.

MacFarlane, S., \& Gavin Sim, M. H. (2005). Assessing usability and fun in educational software. ACM IDC 2005, 103-109.

Masrom, M. (2006). Using SAS to Analyze Student Perspectives on Problem Based-Learning in Computer Science. Paper presented at the SAS Malaysia Forum.

Moser, R. (1997). A fantasy adventure games as a learning environment: Why learning to program is so difficult and what can be done about it. Paper presented at the Proceeding ITiCSE. 
Muratet, M., Torguet, P., Jessel, J.-P., \& Viallet, F. (2009). Towards a Serious Game to Help Students Learn Computer Programming. International Journal of Computer Games Technology, 2009.

Nor Azan, M., \& Wong, S. (2008). Game Based Learning (GBL) Model for History Courseware: A Preliminary Analysis. Paper presented at the International Symposium on Information Technology (ITSIM).

Norizan, M. D. (2003). Pendekatan Bercerita dan Permainan dalam Pembangunan Perisian Kursus Akhlak Islamiah. Unpublished Masters Degree, UKM, Bangi.

Novak, J. (2008). Game Development Essentials: Second Edition. New York: Thomson Delmar Learning.

Oblinger, D. G. (2006). Games and learning :Digital games have the potential to bring play back to the learning experience. Educause quarterly (3), 5-7.

Olga, S., Pavel, V., Alexander, K., \& Alexey, T. (2009). Game based approach in IT education. International Book Series "Information Science and Computing", 12, 63-70.

Olga, S., Voroblakov, P., Kataev , A., \& Tarasenko, A. (2008, June-July 2008). Educational Games for Learning Programming. Paper presented at the Third International Conference "Modern (e-) Learning" Mel 2008 Varna, Bulgaria.

Owen, M. (2004). An anatomy of Games. Retrieved April 2010, [Online] available: www.futurelab.org.uk

Prensky, M. (2001). Digital Game-Based Learning. New York: Mc Graw Hill.

Rajaravivarma, R. (2005). A games-based approach for teaching the introductory programming course. Inroads SIGCSE Bulletin 37(4), 98-102.

Roslina, I., \& Azizah, J. (2009). Educational Games Design Framework: Combination of Game Design, Pedagogy and Content Modeling. Paper presented at the International Conference on Electrical Engineering and Informatics (ICEEI).

Roslina, I., \& Nazli, Y. (2009). Development and effectiveness of educational games for learning introductory programming. CTL Research Report, UTM, Malaysia, Skudai, Johor.

Roslina, I., Rasimah, C. M. Y., \& Azizah, J. (2008). Computer Games Playing Activities: Habits of Universiti Teknologi Malaysia Student. Paper presented at the International Conference on IT and Multimedia (ICIMU), Bangi, Selangor.

Rubijesmin, A. L. (2007). Understanding Malaysian students as gamers: Experience. Paper presented at the Proceedings of the 2nd International Conference on Digital interactive Media in Entertainment and Arts Perth, Australia.

Sauvé, L., Renaud, L., Kaufman, D., \& Marquis, J. S. (2007). Distinguishing between games and simulations: A systematic review. Educational Technology \& Society, 10(3), 247-256.

Sugimoto, M. (2007). What can children learn through game-based learning systems. Paper presented at the 1st IEEE International Workshop on Digital Game and Intellignet Toy Enhanced Learning (DIGITEL '07).

Virvao, M. K., George. Manos Konstantinos (2005). Combining software games with education: Evaluation of its educational effectiveness. Educational Technology \& Society, 8(2), 54-65.

Zarina, S., Alis@Alias, M., Hanawi, S. A., \& Arsad, A. (2005). Faktor-faktor Kegagalan: Pandangan Pelajar Yang Mengulang Kursus Pengaturcaraan C. Paper presented at the ATUR conference, UKM Bangi.

Zuhaira, M. Z. (2007). Pembangunan Perisian Permainan Multimedia untuk Sains Prasekolah: Dam Cuaca. Unpublished Masters Thesis, UKM, Bangi. 
Table 1. Summary of literatures: Educational game studies for learning programming.

\begin{tabular}{|c|c|c|c|c|c|}
\hline No & Author & Genre & Sample & Subject Area & Results \\
\hline 1 & $\begin{array}{l}\text { Shabalina et al } \\
\text { (2009) }\end{array}$ & RPG & & Programming & $\begin{array}{l}\text { No evaluation. Using Ogre3 } \mathrm{D} \text { game } \\
\text { engine and } \mathrm{C}++ \text {. }\end{array}$ \\
\hline 2 & $\begin{array}{l}\text { Muratet et al } \\
(2009)\end{array}$ & & & programming & No evaluation. \\
\hline 3 & $\begin{array}{l}\text { (Jaspaljeet, } \\
\text { 2008) }\end{array}$ & Mini 2D & 5 & Programming & $\begin{array}{l}\text { Children like the game based approach in } \\
\text { learning. }\end{array}$ \\
\hline 4 & $\begin{array}{l}\text { Chang and } \\
\text { Chou (2008) }\end{array}$ & $\begin{array}{l}\text { Maze } \\
\text { game. }\end{array}$ & & Programming & $\begin{array}{l}\text { No evaluation on students. Use } \\
\text { Bomberman by Hudson Soft. }\end{array}$ \\
\hline 5 & $\begin{array}{l}\text { Barnes et al } \\
(2007)\end{array}$ & $\begin{array}{l}\text { Explorator } \\
\text { y and RPG. }\end{array}$ & & $\begin{array}{l}\text { Computer Science. } \\
\text { Use RPGMaker and } \\
\text { NeverWinter Nights } \\
\text { game engine. }\end{array}$ & $\begin{array}{l}\text { Building games to learn computer } \\
\text { sciences. Result: engages students at } \\
\text { multiple levels - inspire new students to } \\
\text { do homework using games and } \\
\text { motivated advanced students to pursue } \\
\text { computing studies. }\end{array}$ \\
\hline 6 & $\begin{array}{l}\text { Connolly et al } \\
\text { (2007) }\end{array}$ & Simulation & & $\begin{array}{l}\text { Software } \\
\text { engineering }\end{array}$ & No evaluation. \\
\hline 7 & Long (2006) & Simulation & 83 & Programming & $\begin{array}{l}\text { Games provide motivation and effectives } \\
\text { in education. }\end{array}$ \\
\hline 8 & $\begin{array}{l}\text { Oh Navarro } \\
\text { and Van Der } \\
\text { Hoek (2005) }\end{array}$ & Simulation & & $\begin{array}{l}\text { Software } \\
\text { engineering } \\
\text { simulation }\end{array}$ & No evaluation. \\
\hline 9 & $\begin{array}{l}\text { Oh Navarro } \\
\text { and Van Der } \\
\text { Hoek (2005) }\end{array}$ & Simulation & & $\begin{array}{l}\text { SimSE process } \\
\text { model }\end{array}$ & No evaluation. \\
\hline 10 & $\begin{array}{l}\text { Rajaravivarma } \\
(2005)\end{array}$ & $\begin{array}{l}\text { Word } \\
\text { games }\end{array}$ & & Programming & No evaluation. \\
\hline 11 & $\begin{array}{l}\text { Gander, } \\
(2002)\end{array}$ & Strategy & 29 & Programming & $\begin{array}{l}\text { The study finds that video games are } \\
\text { especially effective for teaching specific } \\
\text { knowledge. }\end{array}$ \\
\hline
\end{tabular}

Descriptions: This table summarizes literatures on educational games study with focus about learning of programming subject.

Table 2. Educational Games Model and Design Activities

\begin{tabular}{|l|l|}
\hline Model Items & Design Implementations \\
\hline $\begin{array}{l}\text { Learning } \\
\text { Contents }\end{array}$ & $\begin{array}{l}\text { Syllabus of C Programming language used in university. Looping is the main topic } \\
\text { with other basic programming concepts such as data types, variables, constant, } \\
\text { input/output and selections. }\end{array}$ \\
\hline $\begin{array}{l}\text { Characteristics } \\
\text { of online EG }\end{array}$ & $\begin{array}{l}\text { Adapted from features of entertainment games as discussed in EG design } \\
\text { characteristics from previous section. }\end{array}$ \\
\hline $\begin{array}{l}\text { Games } \\
\text { Activities }\end{array}$ & $\begin{array}{l}\text { Game activities is where the students going through the process of playing and } \\
\text { learning. Here is where learner judgements, learner behaviour and system feedback } \\
\text { occurs. Scaffolding designed to help students with the learning contents and provide } \\
\text { them hints/clues to learn or to recover their mistakes. }\end{array}$ \\
\hline $\begin{array}{l}\text { Learning } \\
\text { Outcomes }\end{array}$ & $\begin{array}{l}\text { Each chapters have its own learning outcomes, thus we design the content to meet } \\
\text { the desired outcomes of each concepts/chapters. }\end{array}$ \\
\hline
\end{tabular}

Descriptions: Table 2 shows the activities done during our game design based on items of Input Output Model by

Garris et al (2002). 
Table 3. Students' Motivation

\begin{tabular}{|c|c|c|c|c|c|c|}
\hline No & Statement & Agree & $\begin{array}{l}\text { Not } \\
\text { Sure }\end{array}$ & $\begin{array}{l}\text { Not } \\
\text { agree }\end{array}$ & Mean & $\begin{array}{l}\text { Std. } \\
\text { Dev }\end{array}$ \\
\hline 1 & I think this activity give me lots of benefits & $76 \%$ & $24 \%$ & $0 \%$ & 4.00 & .707 \\
\hline 2 & $\begin{array}{l}\text { I prefer to answer questions this way compared to using books } \\
\text { or paper }\end{array}$ & $67 \%$ & $33 \%$ & $0 \%$ & 4.05 & .865 \\
\hline 3 & I am very interested in using games for learning in the future & $81 \%$ & $19 \%$ & $0 \%$ & 4.19 & .750 \\
\hline 4 & $\begin{array}{l}\text { I prefer to do exercises in games rather than quizzes during } \\
\text { class }\end{array}$ & $81 \%$ & $19 \%$ & $0 \%$ & 4.19 & .750 \\
\hline 5 & $\begin{array}{l}\text { The usage of computer games makes this subject more } \\
\text { interesting }\end{array}$ & $86 \%$ & $14 \%$ & $0 \%$ & 4.29 & .717 \\
\hline
\end{tabular}

Descriptions: Percentage, mean and standard deviations from student motivation items.

Table 4. Students' Attitudes

\begin{tabular}{|l|l|l|l|l|l|l|}
\hline No & Statement & Agree & $\begin{array}{l}\text { Not } \\
\text { Sure }\end{array}$ & $\begin{array}{l}\text { Not } \\
\text { agree }\end{array}$ & Mean & $\begin{array}{l}\text { Std. } \\
\text { Dev }\end{array}$ \\
\hline 1 & I can learn better by myself & $58 \%$ & $42 \%$ & $0 \%$ & 3.67 & .658 \\
\hline 2 & I can learn according my own paced and sequence. & $67 \%$ & $33 \%$ & $0 \%$ & 3.76 & .628 \\
\hline 3 & $\begin{array}{l}\text { It is more flexible for me to determine my own learning } \\
\text { time }\end{array}$ & $57 \%$ & $43 \%$ & $0 \%$ & 3.81 & .814 \\
\hline 4 & It is more flexible for me to choose my learning place & $57 \%$ & $43 \%$ & $0 \%$ & 3.81 & .814 \\
\hline 5 & The content of the games match my subject syllabus & $62 \%$ & $33 \%$ & $0 \%$ & 3.86 & .910 \\
\hline
\end{tabular}

Descriptions: Percentage, mean and standard deviations from students' attitude items.

Table 5. Students' Cognitive Development

\begin{tabular}{|l|l|l|l|l|l|l|}
\hline No & Statement & Agree & $\begin{array}{l}\text { Not } \\
\text { Sure }\end{array}$ & $\begin{array}{l}\text { Not } \\
\text { agree }\end{array}$ & $\begin{array}{l}\text { Mean } \\
\text { Std. } \\
\text { Dev }\end{array}$ \\
\hline 1 & These computer games help me to think critically & $77 \%$ & $23 \%$ & $0 \%$ & 4.05 & .740 \\
\hline 2 & Solving the given problems is very interesting & $81 \%$ & $19 \%$ & $0 \%$ & 4.05 & .669 \\
\hline 3 & It is worth to try using games for learning in future & $81 \%$ & 19 & $0 \%$ & 4.14 & .727 \\
\hline 4 & $\begin{array}{l}\text { Looking for the answer of questions given is an } \\
\text { encouraging activities }\end{array}$ & $76 \%$ & $24 \%$ & $0 \%$ & 4.10 & .768 \\
\hline 5 & These games challenge my understanding of the subject & $71 \%$ & $29 \%$ & $0 \%$ & 4.05 & .805 \\
\hline
\end{tabular}

Descriptions: Percentage, mean and standard deviations from students' cognitive development items. 
Table 6. Game interface

\begin{tabular}{|l|l|l|l|l|l|l|}
\hline No & Statement & Agree & $\begin{array}{l}\text { Not } \\
\text { Sure }\end{array}$ & $\begin{array}{l}\text { Not } \\
\text { agree }\end{array}$ & $\begin{array}{l}\text { Mean } \\
\text { Std. } \\
\text { Dev }\end{array}$ \\
\hline 1 & $\begin{array}{l}\text { Menus available in the games are easy to } \\
\text { understand }\end{array}$ & $67 \%$ & $33 \%$ & $0 \%$ & 3.90 & .768 \\
\hline 3 & $\begin{array}{l}\text { Navigations and interactions are easy to use } \\
\text { Multimedia elements in the games are }\end{array}$ & $72 \%$ & $28 \%$ & $0 \%$ & 4.00 & .775 \\
\hline 4 & $\begin{array}{l}\text { I just need a very short time to know how the } \\
\text { game is functioning }\end{array}$ & $86 \%$ & $14 \%$ & $0 \%$ & 4.14 & .655 \\
\hline 5 & $\begin{array}{l}\text { The use of color and design layout in the games } \\
\text { are interesting }\end{array}$ & $58 \%$ & $38 \%$ & $0 \%$ & 4.00 & .894 \\
\hline
\end{tabular}

Descriptions: Percentage, mean and standard deviations from game interface items.

Table 7. Students Expectation

\begin{tabular}{|c|c|c|c|c|c|c|}
\hline No & Statement & Agree & $\begin{array}{l}\text { Not } \\
\text { Sure }\end{array}$ & $\begin{array}{l}\text { Not } \\
\text { agree }\end{array}$ & Mean & $\begin{array}{l}\text { Std. } \\
\text { Dev }\end{array}$ \\
\hline 1 & $\begin{array}{l}\text { I wish I have more opportunities to learn using } \\
\text { this game approach }\end{array}$ & $71 \%$ & $29 \%$ & $0 \%$ & 4.05 & .805 \\
\hline 2 & $\begin{array}{l}\text { I prefer using games to learn compared to } \\
\text { traditional methods in class }\end{array}$ & $86 \%$ & $14 \%$ & $0 \%$ & 4.19 & .680 \\
\hline 3 & $\begin{array}{l}\text { I would like to learn all computer subjects using } \\
\text { educational games }\end{array}$ & $86 \%$ & $14 \%$ & $5 \%$ & 4.19 & .814 \\
\hline 4 & $\begin{array}{l}\text { I wish this games will be available online for } \\
\text { easy access }\end{array}$ & $77 \%$ & $23 \%$ & $0 \%$ & 4.05 & .740 \\
\hline
\end{tabular}

Descriptions: Percentage, mean and standard deviations from students' expectations items.

Table 8. Some of Students Open Comments

\begin{tabular}{|l|l|}
\hline Student & Comments \\
\hline Student 1 & Fun, not boring and easy to understand \\
\hline Student 2 & More interactive, gain my interest and attention \\
\hline Student 3 & More interesting compare to ordinary ways \\
\hline Student 4 & Improve my thinking skills and help me to memorize the facts better \\
\hline Student 5 & Attract my interest, easy to understand and fun! \\
\hline Student 6 & Interesting and fun \\
\hline Student 7 & More attractive because it is interactive \\
\hline Student 8 & Fun and easy to understand \\
\hline Student 9 & Attractive interface, easy to understand and gain my interest \\
\hline Student 10 & Attractive but may be not as sole learning approach \\
\hline
\end{tabular}

Descriptions: Student open comments of using games as their learning approach. 


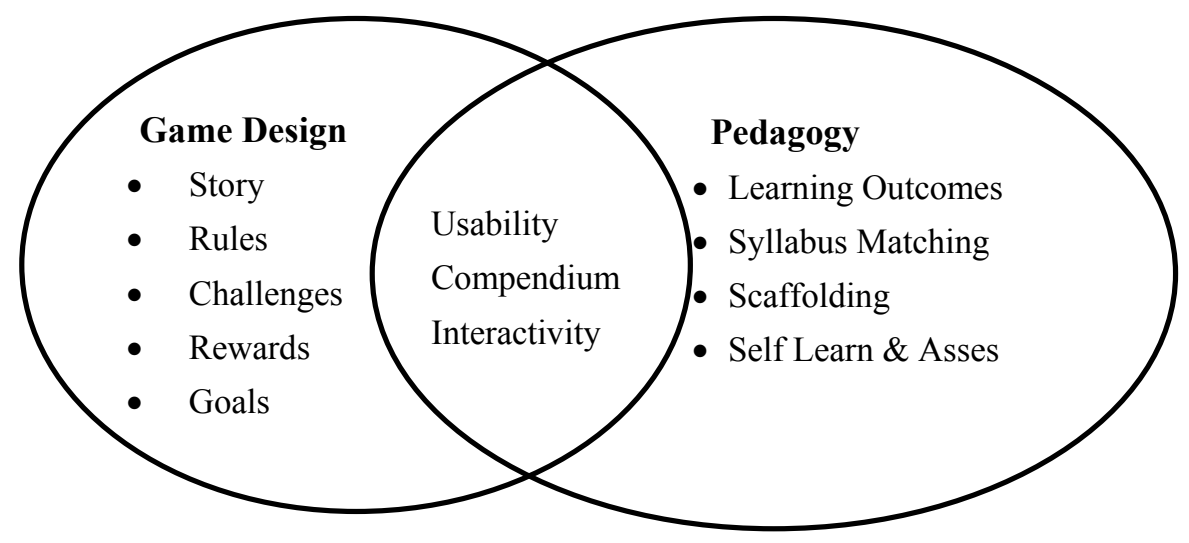

Figure 1. Game Design Conceptual Framework

Descriptions: Figure 1 shows the concept of game design and pedagogy integrated into our educational games for its effectiveness

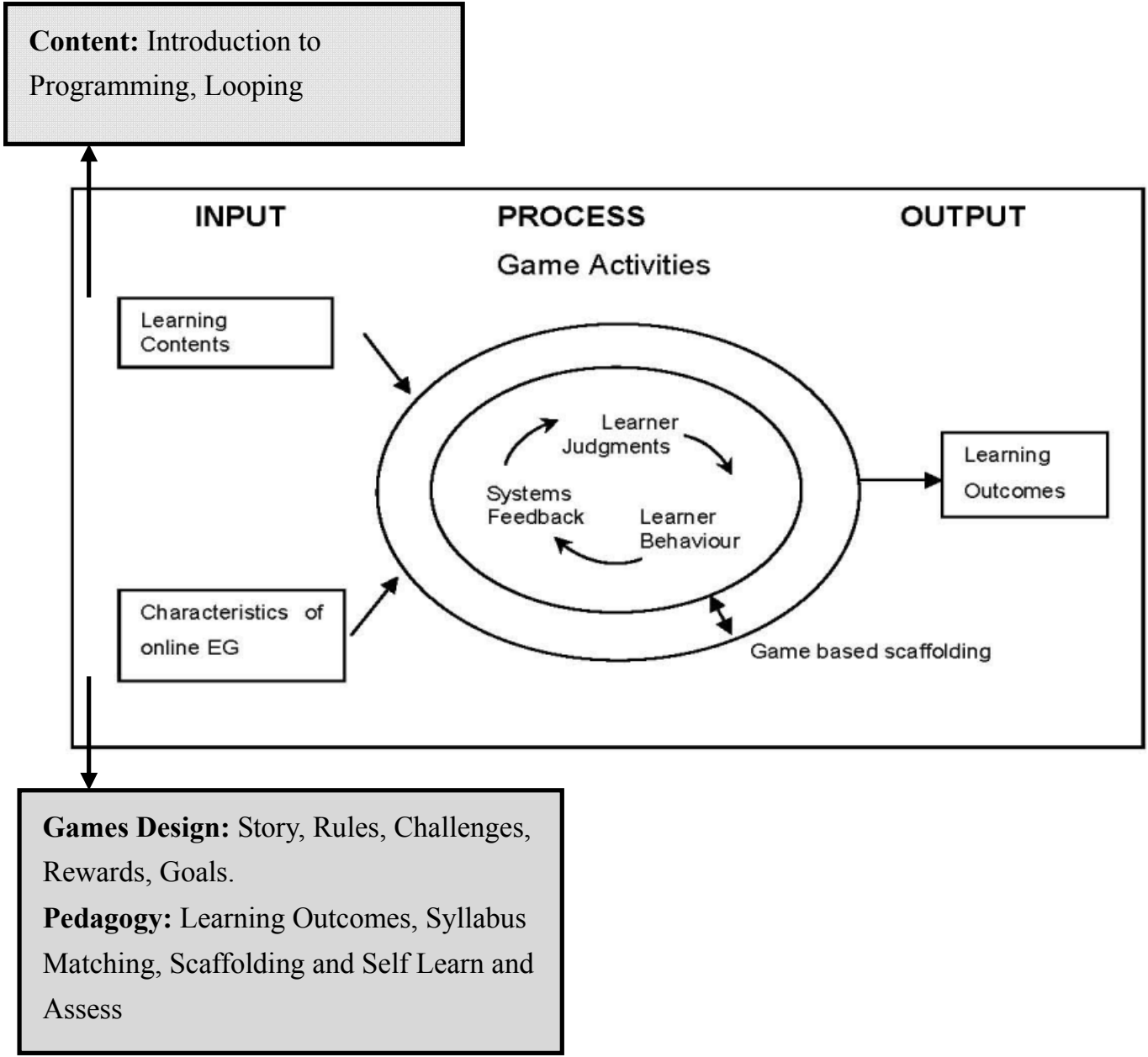

Figure 2. Educational Games Model for Self-learning (Garris et al 2002).

Descriptions: Figure 2 is integration of game concepts into Input Process Output Model in developing educational games to promote motivated learning process that should occur while playing educational games. 


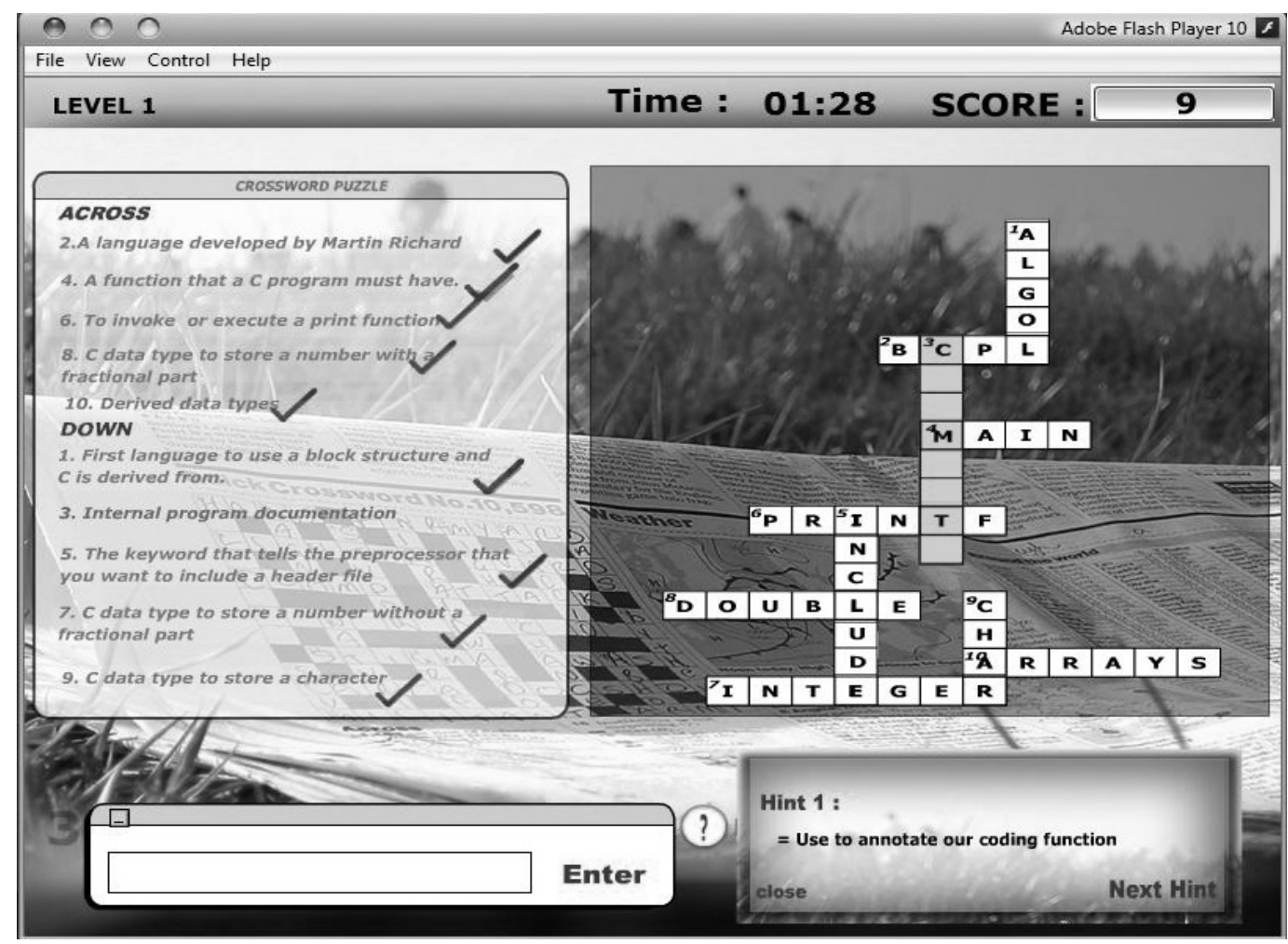

Figure 3. Crossword Games

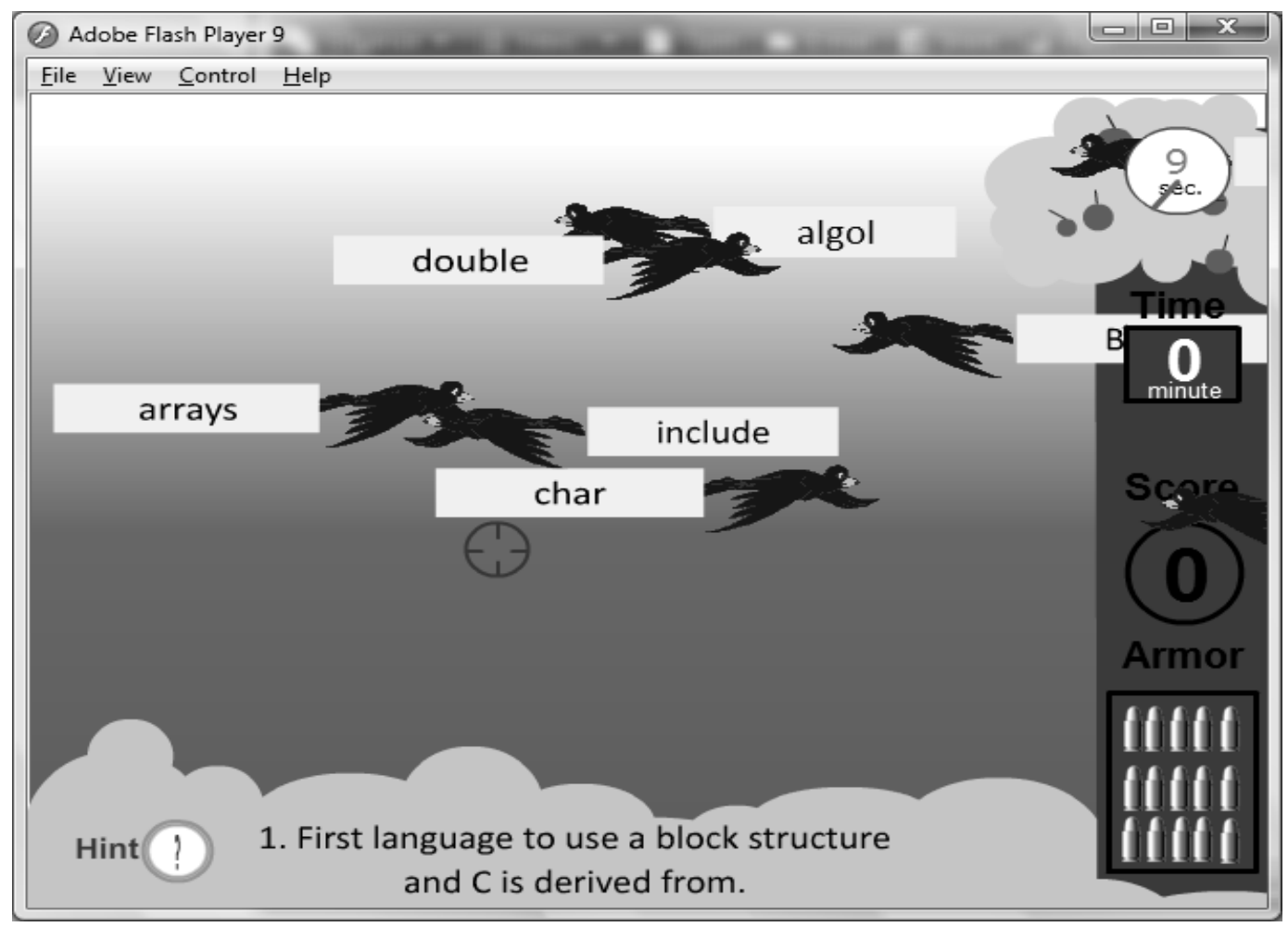

Figure 4. Shooting Games 